\title{
Editorial:
}

\section{INQUA Peribaltic Working Group Excursion and Meeting - active cooperation between Quaternary researchers in the Baltic Sea region}

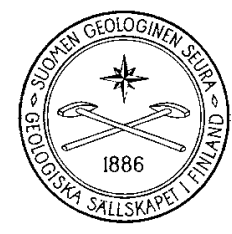

\author{
Pertti Sarala \\ Geological Survey of Finland/Oulu Mining School \\ Rovaniemi, Finland \\ E-mail: pertti.sarala@gtk.fi
}

The INQUA (International Union for Quaternary Research) Peribaltic Working Group meeting with an excursion is an annual field conference which gathers Quaternary researchers from countries around the Baltic Sea together. The field conference is organised every year in a different location. The Peribaltic Working Group is one of the most active working groups of INQUA and its activities are subordinated to the Commission on Terrestrial Processes, Deposits and History (TERPRO). The aim of the working group is to enhance the research co-operation between the countries around the Baltic Sea and to create contacts between researchers in different countries.

In 2017, the field conference took place in Finland (the third time). The topic was 'From past to present - Late Pleistocene, last deglaciation and modern glaciers in the centre of northern Fennoscandia'. The field conference included a five-day-excursion in northern Finland, Sweden and Norway in the middle of August (20th to 25th August) and a one-day seminar with oral and poster presentations at the Kilpisjärvi Biological station in northwestern Finnish Lapland. Altogether 54 researchers from Denmark, France, Germany, Finland, Lithuania, Norway, Poland, Russia and Sweden participated in the conference (Fig. 1).
During the field trip, both the classical localities such as stratigraphical key sites and morphological features in western Finnish Lapland and northern Sweden and new, recently investigated targets in south-western Finnish Lapland were visited. Furthermore, a one-day-visit to the modern glacier in Steindalsbreen, Norway, was included in the excursion program.

The organizers of the field conference in 2017 were the Geological Survey of Finland (GTK) with the help of the Oulu Mining School of the University of Oulu and the University of Stockholm. The INQUA Finnish National Commission and the Peribaltic Working Group also participated in organizing the event. Organizing committee and the leaders of the excursion and the meeting were Prof. Pertti Sarala and Dr. Peter Johansson with the help of Dr. Niko Putkinen, Prof. Juha Pekka Lunkka, Dr. Adrian Hall and Ms Emilia Kosonen. The excursion and meeting were financially supported by GTK and the Council of Finnish Academies.

At the seminar, on $23^{\text {rd }}$ August 2017, 28 oral and 32 poster presentations were given. Based on the abstracts and presentations (see Sarala \& Johansson, 2017) the authors were advised to prepare broader scientific manuscripts for submission to this Peribaltic 2017 Special Issue of the Bulletin of the 


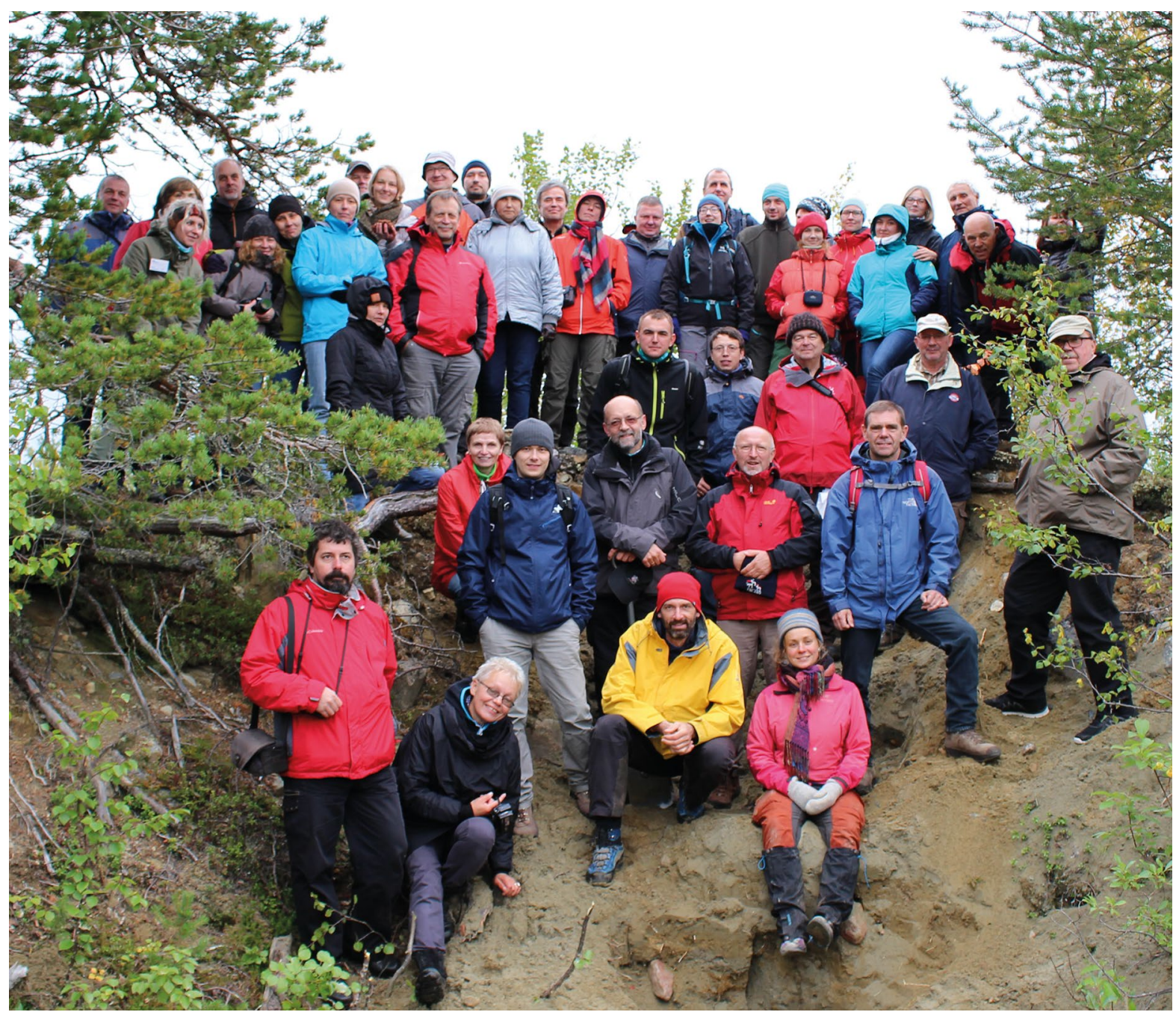

Figure 1. A group photo of the INQUA Peribaltic Working Group meeting and excursion participants in one of the excursion stops on the Pulju moraine ridge close to the Pulju Village, northern Finland. Photo @ GTK.

Geological Society of Finland. A total number of submitted manuscripts was fifteen of which thirteen were accepted for publication in this volume. The abstract volume (Sarala \& Johansson, 2017) is available at GTK's website as an electronic version.

Most of the papers in this volume address the Quaternary deposits and their morphology and research methods in the eastern Baltic Sea region and the marginal areas of last Fennoscandian ice sheet (Poland and Russia). They discuss several types of glaciofluvial and glacial till deposits, ice marginal systems as well as aeolian and fluvial deposits. Watershed kettle-hole basins and the geomorphology of mire basins are reported in two articles. The active tectonics and origin of the fluvial systems in the Vuoksi River valley are also discussed. The inselberg landscape in Finnish Lapland was studied based on the modern LiDAR data interpretation. Finally, the soils of a medieval burial mound are introduced as a paleo-environmental archive in the Leningrad region, Russia.

Thirty volunteers - devoted friends of Quaternary research - have helped me and the Editor-in-Chief by reviewing the manuscripts 
during the editing process of this Special Issue. I and the Geological Society of Finland are deeply indebted to all of them.

\section{In Rovaniemi $1^{\text {st }}$ November 2018}

Pertti Sarala

\author{
Associate Editor \\ Professor, Ph.D., EurGeol \\ Geological Survey of Finland/Oulu Mining School \\ Rovaniemi, Finland \\ E-mail:pertti.sarala@gtk.fi
}

\section{References}

Sarala, P. \& Johansson, P. (eds.), 2017. From past to present - Late Pleistocene, last deglaciation and modern glaciers in the centre of northern Fennoscandia. Excursion guide and abstracts of the INQUA Peribaltic Working Group Meeting and Excursion, 20-25 August 2017. Geological Survey of Finland, Rovaniemi, 175 p. Available online at: https://gtk.verkkokirjasto.fi/web/arena 